\title{
THE IMPLICATIONS OF THE DEMOGRAPHIC DECREASE ON NATIONAL SECURITY
}

\author{
Codrut Ștefan OBREJA \\ "Carol I" National Defense University, Bucharest, Romania \\ obreja_codrut@yahoo.com \\ Ileana-Gentilia METEA \\ "Nicolae Bălcescu" Land Forces Academy, Sibiu, Romania \\ meteaileana@yahoo.de
}

\begin{abstract}
Nowadays the Romanian Armed Forces are subject to a process of modernization of the defence capabilities, and the process is mainly focussed towards the military assets. However, the human factor is decisive in manipulating the new military technology in accordance with its technical specification. In this context we assess that the process of ensuring the proper human resource is a vulnerability factor, and therefore we tackled the demographic decline as a threat for our national security, as it has been less studied in the last period of time. Considering this social phenomenon as one of great importance for our national security, we conducted a research that would lead to pertinent conclusions regarding the trend of the demographic decline and would provide solutions to increase the number and the quality of human resource selected for the military system.
\end{abstract}

KEYWORDS: demographic decrease, vulnerabilities, human resources, migration, military career, national security

\section{Introduction}

Among other vulnerabilities arising from security at the beginning of the millennium, the demographic decline is a typical phenomenon at European level, and we therefore consider that investigating the issues of this wide and complex issue poses a challenge to the in-depth study of the social phenomenon, which may affect national security.

Our approach is focused on several directions that should provide a starting point for possible discussions and subsequent approaches on the influence of the demographic decline on national security. Finally, we seek to identify solutions to counteract the negative effects of the demographic decline on national security.

Thus, in the first part of the activity, we want to address the human resource situation and to emphasize its importance in the context of the need to streamline the Romanian Armed Forces - NATO member Army.

In the second part we will analyze, based on some statistically interpreted data, how large the decrease of the Romanian population is and what its effects are at the level of the Romanian Armed Forces.

In the third part we aim to identify the most efficient solutions that can lead to the provision of human resources in terms of quantity, but more specifically of quality. 
The scientific method used in this study is the content analysis. By interpreting and correlating scientific sources, during this research we would try to identify the challenges regarding the process of human resources selection in the context of the demographic decrease and to find out the proper solutions that would lead to a desired end state in the process of ensuring the quantity and the quality of the human resources for the Romanian Armed Forces.

We believe that this study is particularly useful because it highlights the current challenges of the military career promotion process, personnel recruitment, and the malfunctions that arise during military career management.

All this must be addressed in the current historical context, marked by the obligation to fulfill our national responsibilities or, moreover, as members of the North Atlantic Alliance and the European Union.

2. Aspects to be taken into Consideration in the Analysis of the Human Resources Situation in Romania

The human resource is considered to be the most important resource of an organization, and the aspects related to this resource must be anticipated and treated appropriately from the point of view of ensuring the efficiency of the military organization.
The human resource in the Romanian Armed Forces can be analyzed and treated from the perspective of a coherent set of dimensions: quantitative, normative, structural and psychosocial (Duţu, 2005) to which the qualitative aspect should be added.

The quantitative dimension is given by the number of persons - military and civilian - who are members of a military structure at a certain moment. The number of people varies from one stage of military service to another, depending on political, social, economic and military criteria.

In quantitative terms, human resources in the Romanian Armed Forces are limited by:

- the size of the military units established by the treaties and international conventions to which our country is a party;

- the volume of material resources made available by the society;

- the obligations assumed by Romania as a NATO member state.

As a general trend, the number of employees decreased from 222,508 in 1989 to 109,740 in 2005 and was expected to reach 90,000 (75,000 military employees and 15,000 civilian employees) in 2007 according to PROJECT FORCE 2007 (Chart no. 1).

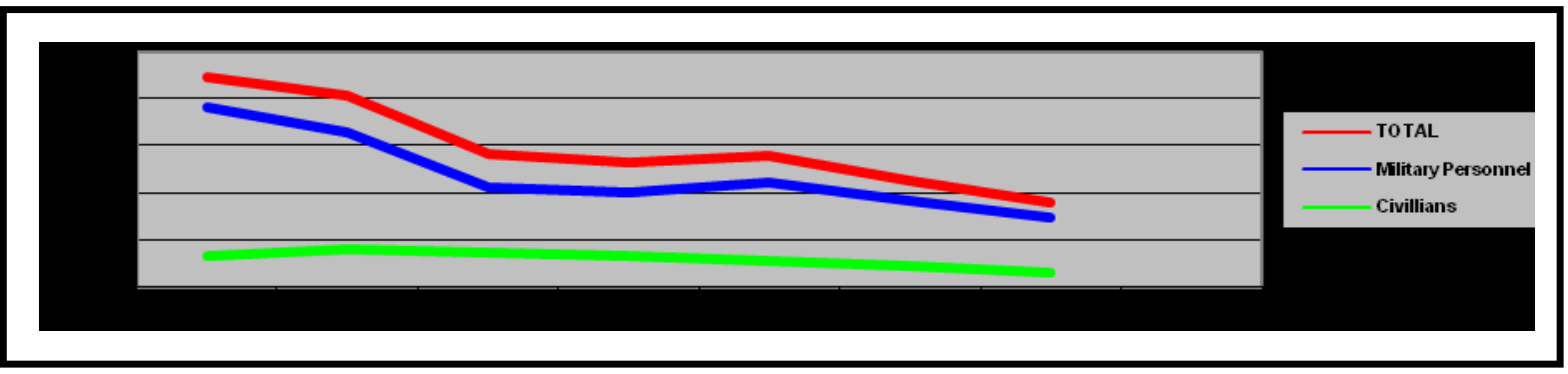

Chart no. 1: Evolution of human resources in the Romanian Armed Forces in the period 1989-2007 (own interpretation)

The normative dimension of the human resources system in the Army has been established and operates on the basis of certain normative acts: Law no. 80 on the Status of Military Staff, as amended and supplemented, Law no. 395 of 16/12/2005 
regarding the suspension in the peacetime of compulsory military service and the transfer to the military service on a voluntary basis, Law no. 384/2006 on the Status of Soldiers and Volunteers, as amended and supplemented, Law no.270 of 2015 on the Status of Military Reservists, Law no. 53 of 2003 - Labor Code, republished, as subsequently amended and supplemented, Government Decision no. 106/2011 - Military Career Guide, Government Decision no. 485/2005 regarding the equivalence of the military functions of the Ministry of National Defense with civilian functions, The Labor Code.

The structural dimension of the human resources of the Romanian Armed Forces reflects the composition of human resources by army force categories, by staff, by military grade, by age and by specialty.

The human resources of the Romanian Armed Forces are made up of officers (leaders), non-commissioned officers and warrant officers (specialists), professional soldiers (executors), civilian personnel who, through their work, ensure the achievement of the military system's objectives, highlighting the other resources.

The Romanian Army has undergone a number of quantitative and structural changes in human resources since the revolution of 1989 according to the needs of the moment, as follows:

- a new category of personnel was set up immediately after the revolution: contracted military employees (currently - professional soldiers);

- the staff of officers and civilians gradually diminished;

- in 2007, a category of soldiers disappeared: the conscripted soldier;

- the number of military and noncommissioned officers diminished and then increased;

- at the moment, the introduction of volunteer reservist service is attempted/intended.
The psychosocial component of the human resources system reflects the existence of a well-structured social structure and a strict hierarchy and derives from all the features and psychological processes of military and civilian personnel. Therefore:

- officers are the military staff of the Armed Forces, military leaders, capable of leading subordinates for missions received, capable of defining and imposing standards of training and behavior;

- NCOs and warrant officers are categories of army military personnel who represent the fighter and military specialist capable of conducting, training and motivating staff of smallscale structures to carry out their missions;

- professional soldiers and sergeants constitute a distinct body of military personnel, recruited on a voluntary basis and which is at the base of the military hierarchy;

- volunteer reservists.

The qualitative dimension of the human resources derives from the necessity to fulfill the obligations deriving from the assumption of Romania's quality as a member of NATO and the European Union. A high-quality military is a precondition for the success of military actions.

From the point of view of assuring the quality of the human resource, the realization of this dimension implies:

- continuous assurance of the professional qualification level of both military employees (officers, warrant and non-commissioned officers) as well as professional soldiers or volunteer reservists;

- a high specialization in accordance with the requirements of the position and function occupied in the organizational chart, as well as with the technical characteristics of the military equipment and the means of fighting. 
Thus, the concept of military professional - a highly qualified person, characterized by competence, responsibility and body spirit (Grigore, 2003), appears. $\mathrm{He}$ has to be an expert because the most modern technical capability is worthless if the staff that has to serve it does not have sufficient skills to exploit it and is not properly motivated, materially and professionally speaking to concentrate on work tasks. Moreover, the complex tasks and objectives in the military field can be accomplished only by suitably qualified people, who are able to do and do what their position (post) implies in the military structure, the better motivated, sentimentally connected with the profession and who voluntarily spend a significant part of their life in the military institution.

\section{The Influence of the Romanian} Population Decrease in Number on the Provision of Human Resources in Romania

After 1989, the numerical evolution of the resident population in Romania is in a downward trend (Table no. 1), the economic and social conditions being the main cause of this demographic decline.

Table no. 1

Evolution of the Romanian population according to population censuses

\begin{tabular}{|c|c|c|c|}
\hline \multirow{2}{*}{$\begin{array}{l}\text { Number of } \\
\text { inhabitants }\end{array}$} & Census 1992 & Census 2002 & Census 2011 \\
\cline { 2 - 4 } & 22.810 .035 & 21.680 .974 & 20.121 .641 \\
\hline
\end{tabular}

(source: http://colectare date. phc/public.do?siteLang=ro)

Unfortunately, it is noted that the demographic trend remains downward, so that on January $1^{\text {st }}, 2017$ the resident population was $19,638,000$ inhabitants, decreasing by 122,000 compared to January $1^{\text {st }}, 2017$ (www.insse.ro/press release no. 212 of 29.08.2017).
Moreover, from the analysis of Chart no. 2, the numerical regression with $30 \%$ of the population under the age of 25 compared to the population aged between 25 and 50 years.

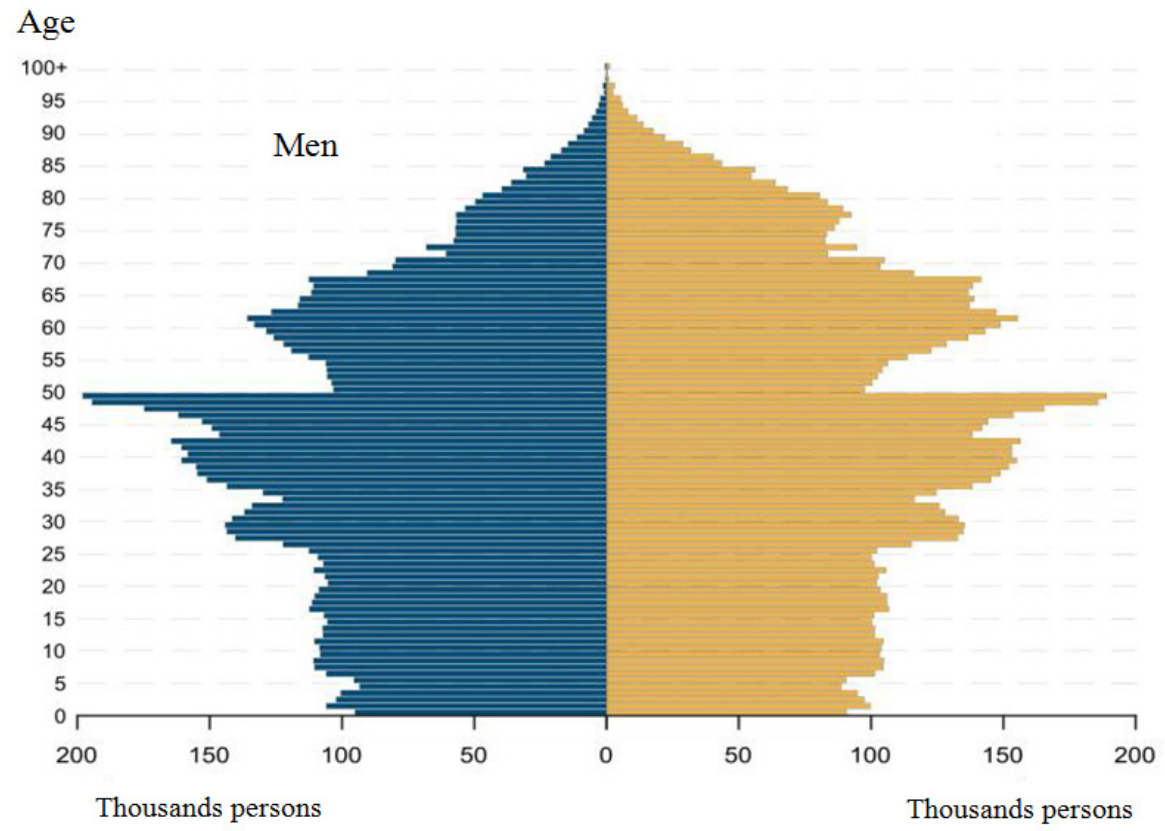

Chart no. 2: The resident population by sex and age, on January $1^{\text {st }}, 2017$ (source: www.insse.ro/ press release no. 212 of 29.08.2017) 
Given the fact that for the category of direct recruitment officers, staff up to the age of 26 is recruited, and for the category of warrant officers personnel with the maximum age of 28 is recruited, which already result in a decrease in the recruitment base of $30 \%$. Continuing the analysis and correlating the resident population with the chart of emigration (Chart no. 3) we conclude that the phenomenon of emigration negatively affects precisely the age groups that could provide eligible personnel for the military profession.

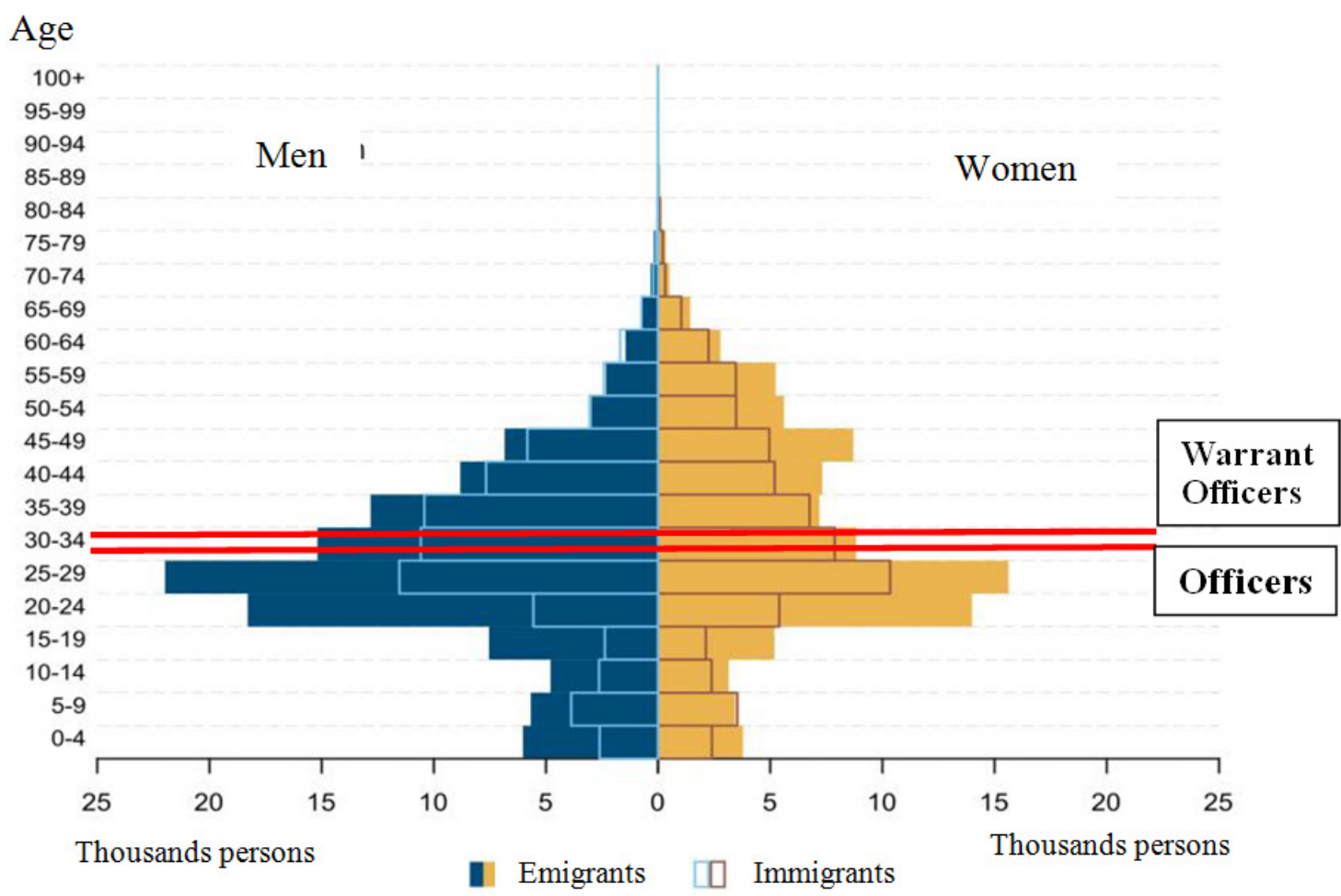

Chart no. 3: Long-term temporary migration by gender and age group in 2016 (source: www.insse.ro/press release no. 212 of 29.08.2017)

If the same trend of emigration is maintained and given that Romania is more of an emigrant country, the numerical regression of the population that can perform the military service will continue.

Regarding the quality of human resources, during the recruitment and selection of candidates for the military profession, the following conclusions were made:

- approximately $25 \%$ of candidates are not medically fit for the categories of staff they are applying for;

- approximately $35 \%$ of the candidates recruited for the officers' profession, $40-45 \%$ of the recruited candidates for the warrant officers' profession, $45 \%$ of the recruited candidates from the NCO profession, $50 \%$ of the candidates recruited for the soldier profession are not declared ADMITTED in the selection process. Even in these circumstances, for the assurance of the quality of human resources in the Ministry of National Defense, 4 candidates on one position are considered optimally to be admitted to military education institutions. It then results that, on average, for a graduate declared ADMITTED in the military higher education institutions, there should be a number of 17 potential candidates. 
Also, following the relationship with potential candidates during the process of promoting in the military career, the following issues emerged:

- generally speaking, young people with high abilities choose to study abroad;

- young people consider that the current recruitment, selection and admission process for the military career is too demanding, this process requiring at least: complex medical visit to the military hospital (usually not done in the home town), selection process at the Regional Selection and Guidance Centers (demanding sports and motivational-aptitude testing, not usually done in the home town), applicant's admission process at the higher education institution (includes an English exam and a two-subject grid test);

- young people consider that the benefits of pursuing military studies are inadequate;

- some of the young graduates want to integrate as quickly as possible into the workforce in Romania or abroad (chart no. 3).

All these economic and social phenomena directly and significantly influence the quality of human resources in the military system, because the selection base is very small.

As regards the recruitment of volunteer reservists, this activity is still pioneering.

\section{Conclusions and Solutions} Identified to Increase the Staff Selection Base in the Military Institution

As regards the increase of the staff selection base for the military institution, it must be assumed that there is fierce competition for resources in the educational and labor market. Competitors are mainly represented by educational institutions of the Ministry of Internal Affairs, as well as fields of activity unrelated to militarized systems.
Regarding the provision of a sufficient number of candidates with adequate motivational-aptitude potential for the military institution, the following short term solutions can be found:

- the operationalization of a military sociology structure at the level of the Human Resources Management Directorate, analyzing socioeconomic phenomena at the level of the society, analyzing the situation of the human resources in the Army for the short, medium and long term, and ensuring the predictability function for establishing the training needs;

- increasing the number of national military colleges to ensure the highest territorial coverage as most of the military college graduates are the guarantee of ensuring the quality of the military officers' and warrant officers' staff;

- implementing an aggressive promotion strategy of the military profession, ensuring the recruitment of candidates with the appropriate motivational-aptitude potential and providing funds for the material base needed for such a campaign;

- appropriate remuneration of military staff and ensuring adequate living conditions for soldiers and their families;

- in order to ensure an adequate number of candidates for the training of warrant officers, it is necessary to reform the education system that ensures their formation. In this respect, if the duration of training for warrant officers discourages young people from pursuing such studies, consideration may be given to granting military status after one year of schooling, and to continue training in military schools and bases/ maintenance centers;

- ensuring a coherent normative framework that can allow a career 
management that meets both the needs of the institution and those of individuals.

- amending the legislation in force to facilitate the admission to a military education institution of members of some Romanian communities outside the country's borders, such as Romanian citizens with a permanent residence in another country, or citizens with Romanian ethnic origin living outside the Romanian territory who do not have Romanian citizenship but speak Romanian and share the same social and cultural values with Romanian citizens, giving them the opportunity to obtain the citizenship of the Romanian state and giving them the opportunity to defend the nation and the national territory, serving the national flag with honor, (an example being the "volohi", members of a Romanian-speaking community living in a territory on the border of Ukraine with the Czech Republic and Poland, the descendants of emigrated Romanians or even of minorities who lived in Romania and whose descendants have Romanian citizenship).

\section{REFERENCES}

Duţu, P. (2005). Impactul integrării în Alianţa Nord-Atlantică asupra managementului resurselor umane din Armata României, Bucureşti: Editura Universităţii Naţionale de Apărare.

Grigore, L. (2003). Profesionalizarea Armatei României - Studii de artă militară şi managementul resurselor umane, Sibiu: Editura Hermannstadt.

Institutul Naţional de Statistică, Statistică oficială din România, available at: http//www.insse.ro, accessed on: 03.02.2018. 